\title{
Denitrifying microbial communities along a boreal stream with varying land-use
}

\author{
Sanni L. Aalto ${ }^{1,2} \mathbb{D} \cdot$ Jatta Saarenheimo ${ }^{2} \cdot$ Lauri Arvola $^{3} \cdot$ Marja Tiirola $^{2,4} \cdot$ Jussi Huotari $^{3} \cdot$ Antti J. Rissanen $^{5}$
}

Received: 28 January 2019 / Accepted: 13 July 2019 / Published online: 24 July 2019

(c) The Author(s) 2019

\begin{abstract}
Streams have an important role in regulating nitrogen $(\mathrm{N})$ transportation from terrestrial ecosystems to downstream waters. Here, we examined how catchment land-use affects potential denitrification rates and the function and composition of denitrifier communities in boreal stream sediments, using stable isotope incubations and qPCR and 454-pyrosequencing targeted on nirS, nirK and nosZ genes. Although land-use influenced the water chemistry as higher nitrite + nitrate $\left(\mathrm{NO}_{\mathrm{x}}^{-}\right)$ concentration at the agriculture-affected sampling point, sediment organic matter content was found to be the key factor in regulating potential denitrification rates. However, the abundance as well as the diversity and community composition of denitrifying microbes, and genetic $\mathrm{N}_{2} \mathrm{O}$ production potential (the ratio between $\operatorname{nir} S+\operatorname{nir} K$ and $n o s Z$ gene abundances) were connected to both $\mathrm{NO}_{\mathrm{x}}^{-}$and sediment quality. Overall, our results suggest that catchment land-use-driven changes in $\mathrm{N}$ and carbon availability affect the denitrification rates, and possibly $\mathrm{N}_{2}: \mathrm{N}_{2} \mathrm{O}$ production ratio, in boreal streams, through altering denitrifier abundance and community composition.
\end{abstract}

Keywords Catchment land-use $\cdot$ Community composition $\cdot$ Denitrification $\cdot \operatorname{nir} S+\operatorname{nirK} \cdot \operatorname{nos} Z \cdot 454$-Pyrosequencing

\section{Introduction}

Electronic supplementary material The online version of this article (https://doi.org/10.1007/s00027-019-0654-z) contains supplementary material, which is available to authorized users.

Sanni L. Aalto

sanni.aalto@uef.fi

1 Department of Environmental and Biological Sciences, University of Eastern Finland, P.O. Box 1627 70211 Kuopio, Finland

2 Department of Biological and Environmental Science, University of Jyväskylä, P.O. Box 35, 40014 Jyväskylä, Finland

3 Lammi Biological Station, Faculty of Biological and Environmental Sciences, Ecosystems and Environment Research Programme, Pääjärventie 320, 16900 Lammi, Finland

4 Nanoscience Center, Department of Biological and Environmental Science, University of Jyväskylä, P.O. Box 35, 40014 Jyväskylä, Finland

5 Bio and Circular Economy Research Group, Faculty of Engineering and Natural Sciences, Tampere University, Korkeakoulunkatu 10, 33720 Tampere, Finland
Anthropogenic activities such as application of nitrogen $(\mathrm{N})$ fertilizers and waste disposals have substantially increased $\mathrm{N}$ loadings into aquatic ecosystems (e.g. rivers, lakes; Galloway et al. 2014). Streams have an important role in regulating $\mathrm{N}$ transport, acting as entries for the terrestrial material to the hydrological continuums of rivers, lakes and oceans. Even small streams may have relatively high inorganic nitrogen removal capacity, and can retain substantial amounts of biologically reactive inorganic $\mathrm{N}$ species, ammonium and nitrate, through assimilation to the biotic material, sedimentation or denitrification (Peterson et al. 2001; Jarvie et al. 2018). Denitrification is a microbial process, where inorganic $\mathrm{N}$ (nitrate) can be reduced to biologically inert nitrogen gas $\left(\mathrm{N}_{2}\right)$, which is then released from the ecosystem, making it the only process truly removing $\mathrm{N}$ from the systems. Denitrification is a sequential process with four enzymatic steps. Genes coding for enzymes reducing nitrite $\left(\mathrm{NO}_{2}^{-}\right)$to nitric oxide (NO), nirS and nirK, are the most widely used molecular markers to study denitrifier populations. Besides nitrite reductases, nitrous oxide $\left(\mathrm{N}_{2} \mathrm{O}\right)$ reductase (coded by nosZ) has an important role in controlling the final step of denitrification, and the high ratio between the 
abundances of nir and nos genes has found to be an indicator for the high potential production of greenhouse gas $\mathrm{N}_{2} \mathrm{O}$ (Saarenheimo et al. 2015a).

In streams, denitrification rates are expected to increase with nitrate concentrations (Seitzinger et al. 2006), although oxygen concentration and temperature may be more important factors in driving seasonal variations in stream denitrification rates (Inwood et al. 2005; Jarvie et al. 2018). Higher phosphorus availability has been suggested to promote instream denitrification as well (Eberhard et al. 2018). Furthermore, the proportion of removed $\mathrm{N}$ has been found to decrease in agricultural streams with high $\mathrm{N}$ concentrations, which is mainly explained as organic matter availability limiting the process (Inwood et al. 2005, 2007; Arango et al. 2007; Mulholland et al. 2008).

Boreal aquatic ecosystems exhibit lower $\mathrm{N}$ removal rates than the ones in the temperate area (Rissanen et al. 2013), suggesting that a higher proportion of catchment $\mathrm{N}$ loading may be exported through stream-river-lake-continuums, and eventually discharged to vulnerable areas, such as the Baltic Sea. However, increasing anthropogenic N loading can promote denitrifying communities and denitrification in the boreal water bodies (Bruesewitz et al. 2011; Aalto et al. 2018). Here, we examined the genetic potential and composition of sediment denitrifying microbial communities along a gradient of different land-use types in a boreal stream, using quantitative polymerase chain reaction (qPCR) and 454-pyrosequencing targeted at nirS, nirK and nos Z genes. In addition, we measured sediment denitrification rates with isotope pairing technique (IPT) method (Nielsen 1992). We hypothesized that the stream microbial habitat conditions, reflecting the catchment land-use, shape the composition and function of denitrifying microbes and rates of denitrification.

\section{Materials and methods}

\section{Sample and data collection}

Löytynoja is a first-order stream $(\sim 4.5 \mathrm{~km})$ in Southern Finland, which originates from a groundwater spring and discharges into the oligo-mesotrophic Lake Pääjärvi. Sampling was conducted along the stream at four points between 22 and 29 July 2010 (Fig. 1; Table 1). The sampling points differ in their catchment area and land-use (Table 1).

Sampling point $\mathrm{S} 1$ is located to the upper reaches of the stream with forest-dominated catchment area, point S2 is agriculture-dominated and receives high amounts of agricultural runoff. Sampling points S3 and S4 are located in the lower part of the stream, where the influence of drained

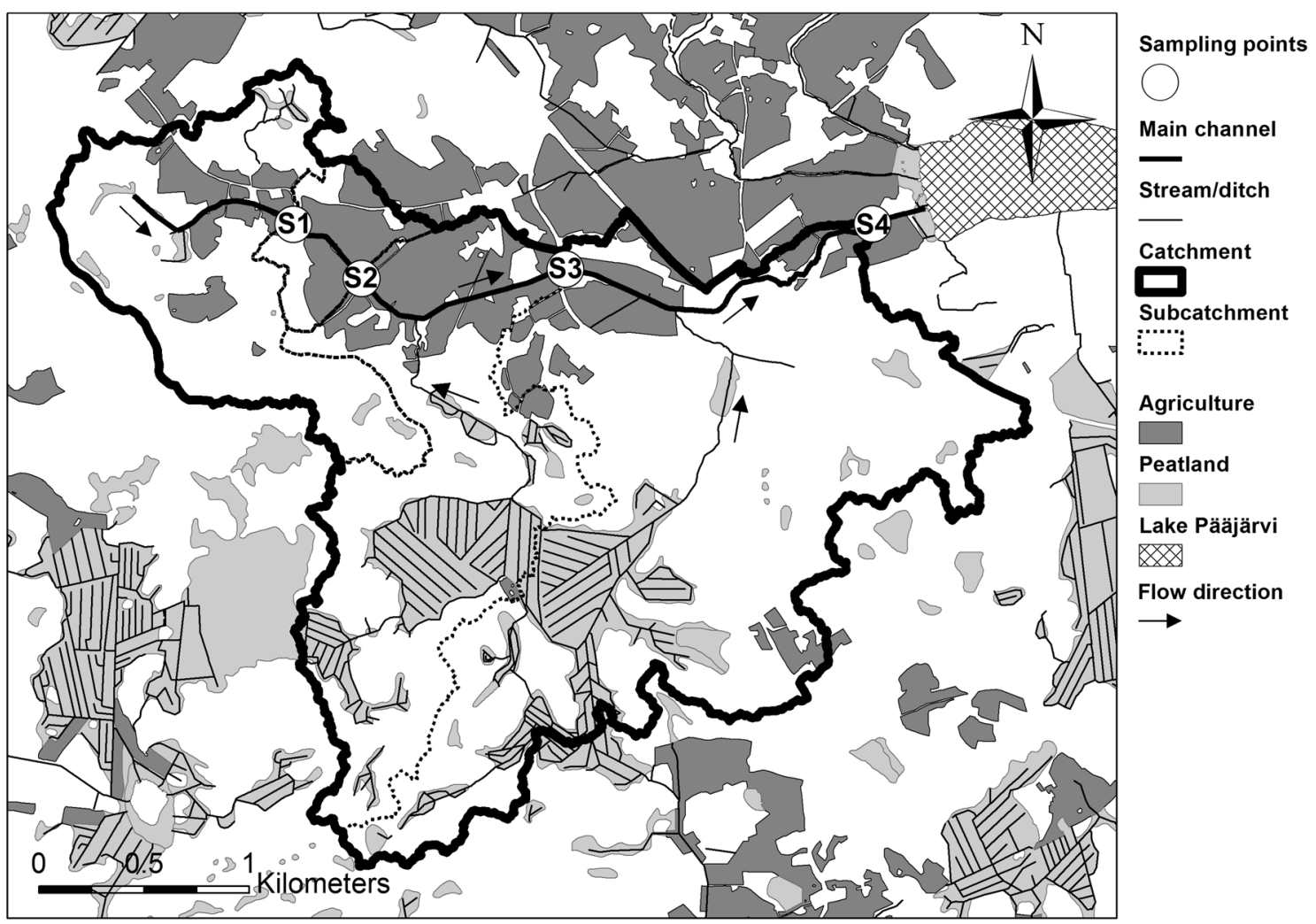

Fig. 1 Map of stream Löytynoja catchment area. The white areas represent forest or built areas 
Table 1 The environmental variables in water above the sediment surface (oxygen: $\mathrm{O}_{2}$, temperature: temp, $\mathrm{pH}, \mathrm{DOC}$ : dissolved organic carbon, $\mathrm{NO}_{\mathrm{x}}^{-}$: nitrite and nitrate, $\mathrm{PO}_{4}^{-}$: phosphate, $\mathrm{NH}_{4}^{+}$: ammonium, TN: total nitrogen, TP: total phosphorus), and of the sediment
(LOI\%: the proportion of organic matter, \%C: sediment carbon content, $\% \mathrm{~N}$ : sediment nitrogen content), catchment area (land area), the proportions of each land-use type, and the denitrification potential (D15) at four sampling points

\begin{tabular}{|c|c|c|c|c|c|c|c|c|c|c|}
\hline $\begin{array}{l}\text { Sampling } \\
\text { point }\end{array}$ & $\begin{array}{l}\text { Sampling } \\
\text { date }\end{array}$ & $\mathrm{O}_{2} \%$ & Temp & $\mathrm{pH}$ & DOC $(\mathrm{mg} / \mathrm{l})$ & $\mathrm{NO}_{\mathrm{x}}^{-}(\mu \mathrm{mol} / \mathrm{l})$ & $\mathrm{PO}_{4}^{-}(\mu \mathrm{mol} / \mathrm{l})$ & $\mathrm{NH}_{4}^{+}(\mu \mathrm{mol} / \mathrm{l})$ & $\mathrm{TN}(\mu \mathrm{mol} / \mathrm{l})$ & $\mathrm{TP}(\mu \mathrm{mol} / \mathrm{l})$ \\
\hline S1 & 22 July 10 & 90.6 & 9.3 & 7.0 & 1.8 & 55.4 & 0.06 & 0.64 & 57.9 & 0.23 \\
\hline $\mathrm{S} 2$ & 28 July 10 & 93.5 & 8.8 & 6.9 & 1.8 & 74.8 & 0.23 & 0.71 & 83.2 & 0.68 \\
\hline S3 & 29 July 10 & 94.7 & 10.5 & 6.9 & 2.3 & 61.4 & 0.06 & 3.14 & 70.5 & 0.68 \\
\hline \multirow[t]{2}{*}{ S4 } & 23 July 10 & 95.5 & 12 & 7.2 & 2.8 & 48.5 & 0.10 & 1.93 & 52.3 & 0.58 \\
\hline & LOI\% & $\% \mathrm{C}$ & \multicolumn{2}{|l|}{$\% \mathrm{~N}$} & \multicolumn{2}{|c|}{ Land area (ha) } & Field (\%) & Peatland (\%) & Forest (\%) & $\begin{array}{l}\mathrm{D} 15(\mu \mathrm{mol} \mathrm{N} / \\
\left.\mathrm{m}^{2} / \text { day }\right)\end{array}$ \\
\hline S1 & 4.50 & 0.73 & \multicolumn{2}{|c|}{0.05} & 14,928 & \multicolumn{2}{|l|}{13.4} & 2.9 & 83.7 & 36.9 \\
\hline S2 & 6.25 & 2.95 & \multicolumn{2}{|c|}{0.29} & 3266 & \multicolumn{2}{|l|}{62.9} & 0 & 37.1 & 423.5 \\
\hline S3 & 3.05 & 0.99 & \multicolumn{2}{|c|}{0.05} & 22,083 & \multicolumn{2}{|l|}{18.1} & 23.8 & 58.0 & 16.1 \\
\hline S4 & 5.18 & 2.26 & \multicolumn{2}{|c|}{0.18} & 41,107 & \multicolumn{2}{|l|}{7.8} & & 76.9 & 456.4 \\
\hline
\end{tabular}

peatlands is higher than at the two other points. At S4, located near Pääjärvi where stream water is eventually discharged, there is a gauging station with spillway weir decreasing the water velocity (Fig. 1). More information of the stream can be found from Hakala et al. (2002), Huotari et al. (2013), and Arvola et al. (2015). The catchment area for each sampling point was delineated from digital elevation model (pixel size $2 \mathrm{~m}$ ) based on a laser scanning (National Land Survey of Finland 2016), and the proportions of different land-use types (i.e. forest, agriculture, and peatland; Table 1) were defined using Topographic Database of National Land Survey of Finland (2010) and analysis with ArcMap 10. The catchment areas of the sampling points represent only the additional land area following the previous upstream sampling points and do not overlap. This approach was used since we wanted to focus only on the nearest catchment area, where most of the runoff is coming to the sampling point, rather than on the entire upper stream catchment area.

Four sediment cores (diameter of $7 \mathrm{~cm}$ ) were collected from each sampling point using plexiglass tubes. Water temperature, oxygen concentration, and $\mathrm{pH}$ were measured above the sediment surface at each sampling point. Water carbon and nutrient content were analysed using Lachat's Flow Injection Analysis System $\left(\mathrm{NO}_{3}{ }^{-}+\mathrm{NO}_{2}{ }^{-}, \mathrm{NH}_{4}{ }^{+}\right.$, $\mathrm{PO}_{4}{ }^{3-}$, TN, and TP) and Shimadzu TOC 5000 analyzer (DOC) with standard methods (Arvola et al. 2014). Sediment porosity and organic matter content (LOI\%, loss on ignition) were measured as previously described (Rissanen et al. 2011), and sediment $\% \mathrm{~N}$ and $\% \mathrm{C}$ were measured from freeze-dried samples using Carlo-Erba Flash 1112 series Elemental Analyser (Thermo Scientific, Waltham, MA, USA). For DNA extractions, four subsamples were taken from the sediment surface layer (depth of 0-1 cm) and four subsamples were taken from the lower sediment layers (deep sample from depths $1-5 \mathrm{~cm}$ ). Samples were slurried, divided into $200 \mu \mathrm{l}$ aliquots, and stored at $-20^{\circ} \mathrm{C}$, as in Rissanen et al. (2011).

\section{Sediment denitrification rates}

For measuring potential (D15) and actual (D14) denitrification rates, three to four subcores were taken using small plastic tubes (length $16 \mathrm{~cm}$, diameter $2.6 \mathrm{~cm}$ ) from each sediment core as in Rissanen et al. (2011). Shortly, the tubes were pushed into the sediment so that approximately $4-7 \mathrm{~cm}$ of the tube length was filled with sediment, and the rest with overlying water. Following IPT (isotope pairing technique; Nielsen 1992), subcores were incubated with ${ }^{15} \mathrm{NO}_{3}{ }^{-}$-label $(20,70,120 \mu \mathrm{M})$ with a magnetic stirrer on the lid of the cores, at in situ temperature and darkness. After $3 \mathrm{~h}$, microbial activity was terminated by adding $1 \mathrm{ml}$ $\mathrm{ZnCl}_{2}(1 \mathrm{~g} / \mathrm{ml})$, subcores were mixed, and subsamples of the sediment-water slurry were transferred to gas-tight glass vials (12 ml; Exetainer ${ }^{\circledR}$; Labco). The $\mathrm{N}_{2}$ isotopic composition was measured with an isotope ratio mass spectrometer (Roboprep-G-+ and Tracermass, Europa Scientific) at the National Environmental Research Institute in Silkeborg, Denmark.

\section{qPCR of nirS, nirk, and nosZ}

Nucleic acids were extracted from sediment samples using a modified version of the bead-beating and phenol-chloroform extraction protocol of Griffiths et al. (2000) (see Rissanen et al. (2010) for further details). The abundance of nir $S$, nirK, and nos $Z$ genes were measured with quantitative PCR (qPCR) as in Saarenheimo et al. (2015b). Before qPCR, 
the four subsamples samples from each sampling depth and sampling point were pooled, resulting in eight samples in total. We used nirSCd3aF/nirSR3cd (Kandeler et al. 2006) primer pair for nirS, nirK876/nirK1040 (Henry et al. 2004) for nirK, and nosZ2F/nosZ2R (Henry et al. 2006) for nosZ. Annealing temperatures were $55{ }^{\circ} \mathrm{C}$ for $n i r S$, and $60{ }^{\circ} \mathrm{C}$ for nirK and nosZ. No template inhibition was observed, when qPCR linearity was tested from original, 10- and 100-fold template dilution series (Saarenheimo et al. 2015b).

\section{Pyrosequencing}

The community structure, richness and diversity of organisms harbouring nirS, nirK and nosZ genes were studied using 454-pyrosequencing. PCR was conducted with primer pairs nirScd3aF/nirSR3cd for nirS (Kandeler et al. 2006), $\mathrm{F} 1 \mathrm{aCu} / \mathrm{R} 3 \mathrm{Cu}$ for $\operatorname{nirK}$ (Hallin and Lindgren 1999), and nosZF/nosZ1622R for nosZ (Kloos et al. 2001; Throbäck et al. 2004) from four replicate sediment samples following Saarenheimo et al. (2015b). The sequencing and sequence data analysis were conducted as in Saarenheimo et al. (2015b) using samples pooled for sampling point and depth $(\mathrm{n}=8)$. Sequences were subsampled (610 for nirK, 652 for nirS, and 312 for nosZ), classified into operational taxonomical units (OTUs) at the 90\% similarity level, and community diversity (Shannon index; estimator of species richness and species evenness), species richness (Chao1 richness estimate; abundance-based estimator of species richness; Chao 1984), and a coverage estimate of the proportion of amplified gene amplicons represented by sequence libraries for each sample (Good's coverage) were calculated in Mothur (Schloss et al. 2009). Nucleotide sequences were assigned to taxonomies in Mothur following Saarenheimo et al. (2015b). The 454-pyrosequencing data were deposited to the NCBI's Sequence Read Archive under accession number SRP150895.

\section{Statistical analysis}

All statistical analyses were conducted using $\mathrm{R}$ version 3.3.3 (R Core Team, 2017). Using the relative abundances of the most dominant OTUs (OTUs comprising $>80 \%$ of sequences across all samples), samples were UPGMA clustered, and heatmaps were created using function "pheatmap" in $\mathrm{R}$. The relationships between environmental variables, land-use types, and gene abundances and their ratios, or diversity and species richness of the communities were studied with Spearman correlation.

\section{Results and discussion}

\section{Environmental variables and denitrification rates}

In Löytynoja, nutrient and carbon concentrations changed along the hydrological pathway from upstream to downstream due to the land-use of the sampling points (Table 1). Dissolved organic carbon as well as ammonium increased from the forest-dominated S1 to the S3 and S4, where peatland contributed more to the water quality, agreeing with the previous findings on the higher proportion of peatland in the catchment increasing DOC concentrations (Huotari et al. 2013; Laine et al. 2014), and on high ammonium loading coming from drained peatlands (Laine et al. 2013; Arvola et al. 2015). Nitrite + nitrate, phosphate, TN and TP peaked at agriculture-dominated S2, as observed previously in Löytynoja and in other agriculture-affected streams (Hakala et al. 2002; Inwood et al. 2005). In contrast to water chemistry, sediment quality $(\% \mathrm{C}, \% \mathrm{~N}$, and $\mathrm{LOI} \%)$ varied less consistently, being high both at S2 and S4, although these points had a different land-use coverage. At S2, agricultural loading with high organic matter content explains the result (Inwood et al. 2007). At S4, this result can be explained with the dam decreasing water velocity and leading to accumulation of organic matter coming from the upper catchment area and also from the previous sampling points. It seems that sediment quality was partly explained with land-use and partly with streambed characteristics and water velocity.

In IPT samples, the D15 did not increase in parallel with ${ }^{15} \mathrm{~N}$-labeled nitrate concentration (Suppl. Figure 1), hence, the assumption of nitrate- limitation of denitrification in the IPT was not met (Nielsen 1992). Therefore, it was possible to calculate only potential denitrification as the average of D15 measured from cores receiving $120 \mu \mathrm{mol} / 1{ }^{15} \mathrm{NO}_{3}$ addition. We found that $\mathrm{S} 2$ and $\mathrm{S} 4$ were denitrification hotspots, the denitrification potential (D15) being 12-28 fold higher there as compared to S1 and S3 (Table 1). According to the correlation analysis, D15 increased with sediment quality (\% $\mathrm{C}: \rho=0.94, \mathrm{p}<0.001$, $\% \mathrm{~N}: \rho=0.87, \mathrm{p}<0.001$, LOI: $\rho=0.78, \mathrm{p}<0.001)$, and with the stream water phosphate, but was not connected to nitrite + nitrate ( $p>0.05$; Suppl. Figure 2). In this environment, denitrification was expected to be mainly heterotrophic, so our result indicates that nitrate levels were always adequate, but carbon availability was regulating denitrification potential, explaining the lower denitrification potential found at S1 and S3 with low sediment C content. Previously, denitrification has found to be limited with carbon, or co-limited with nitrate and carbon in nitrate-rich streams (Arango et al. 2007; Inwood et al. 2007), and recently, higher nitrate uptake fluxes (Tomasek 
et al. 2018) and denitrification rates (Eberhard et al. 2018) were found in carbon-amended than in unamended stream sediments. Together with these previous findings, our results highlight the key role of carbon in supporting beneficial nitrate reduction in stream environments.

\section{Genetic denitrification potential}

The abundance patterns of the three denitrification genes were not uniform (Fig. 2). There were some differences in the gene abundances between the surface and deeper sediment samples between the sampling points, as deeper samples had higher genetic denitrification potential than surface samples at S3 and S4 (Fig. 2), and vice versa at S1 and S2. This could be explained with the active denitrification zone being wider at $\mathrm{S} 3$ and $\mathrm{S} 4$, possible due to higher sedimentation rate or different sediment characteristics than at $\mathrm{S} 1$ and S2. However, the abundance pattern was similar in surface and deep samples, the abundance of nirS being highest at $\mathrm{S} 1$ and S3, and related neither to land-use nor water inorganic $\mathrm{N}$ concentrations (Spearman correlation, $\mathrm{p}<0.05$ ). In contrast, the abundances of nirK and nosZ increased with nitrite + nitrate (nirK: $\rho=0.95, \mathrm{p}<0.001$, nosZ: $\rho=0.90$, $\mathrm{p}<0.001)$ and sediment organic matter (nirK: $\rho=0.71$, $\mathrm{p}=0.001$, nos $Z: \rho=0.78, \mathrm{p}<0.001)$, decreased with ammonium (nirK: $\rho=-0.78, p<0.001$, nos $Z$ : $\rho=-0.91$, $\mathrm{p}<0.001$ ), and were related to land-use (field\% vs. nirK: $\rho=0.96, p<0.001$, nosZ: $\rho=0.93, p<0.001)$, peaking at the agriculture-dominated S2 (Suppl. Figure 2). These results suggest that nirS and nirK exhibited some niche separation, since nirK carrying denitrifiers were more sensitive to environmental variation, as has been previously observed in soil environments (e.g. Enwall et al. 2010). In addition, the results indicate that genetic denitrification potential increased with higher availability of substrates and electron donors, the denitrification gene abundance being highest at the agriculture-dominated sampling point with high nitrite + nitrate and sediment organic matter availability.

To further estimate the genetic potential for $\mathrm{N}_{2}$ production, we examined the relationship between nitrite reduction genes (nir $S+n i r K)$ and nitrous oxide reduction gene (nosZ). We acknowledge that our primer pair could not amplify nos $Z_{I I}$ clade (Sanford et al. 2012; Jones et al. 2013), and thus we captured only a part of nos $Z$ population. However, the ratio between nir $S+$ nirK and nos $Z$ has indeed been found to be the one to govern $\mathrm{N}_{2} \mathrm{O}$ reduction potential in boreal lakes, an increase in the ratio indicating higher genetic potential for $\mathrm{N}_{2} \mathrm{O}$ than for $\mathrm{N}_{2}$ production, and a decrease in the ratio indicating higher $\mathrm{N}_{2}$ production potential (Saarenheimo et al. 2015a). The nir $S+$ nirK/nos $Z$ ratio followed land-use patterns by increasing with higher proportion of peatlands and ammonium (peatland $\%: \rho=0.89, p<0.001$, ammonium:

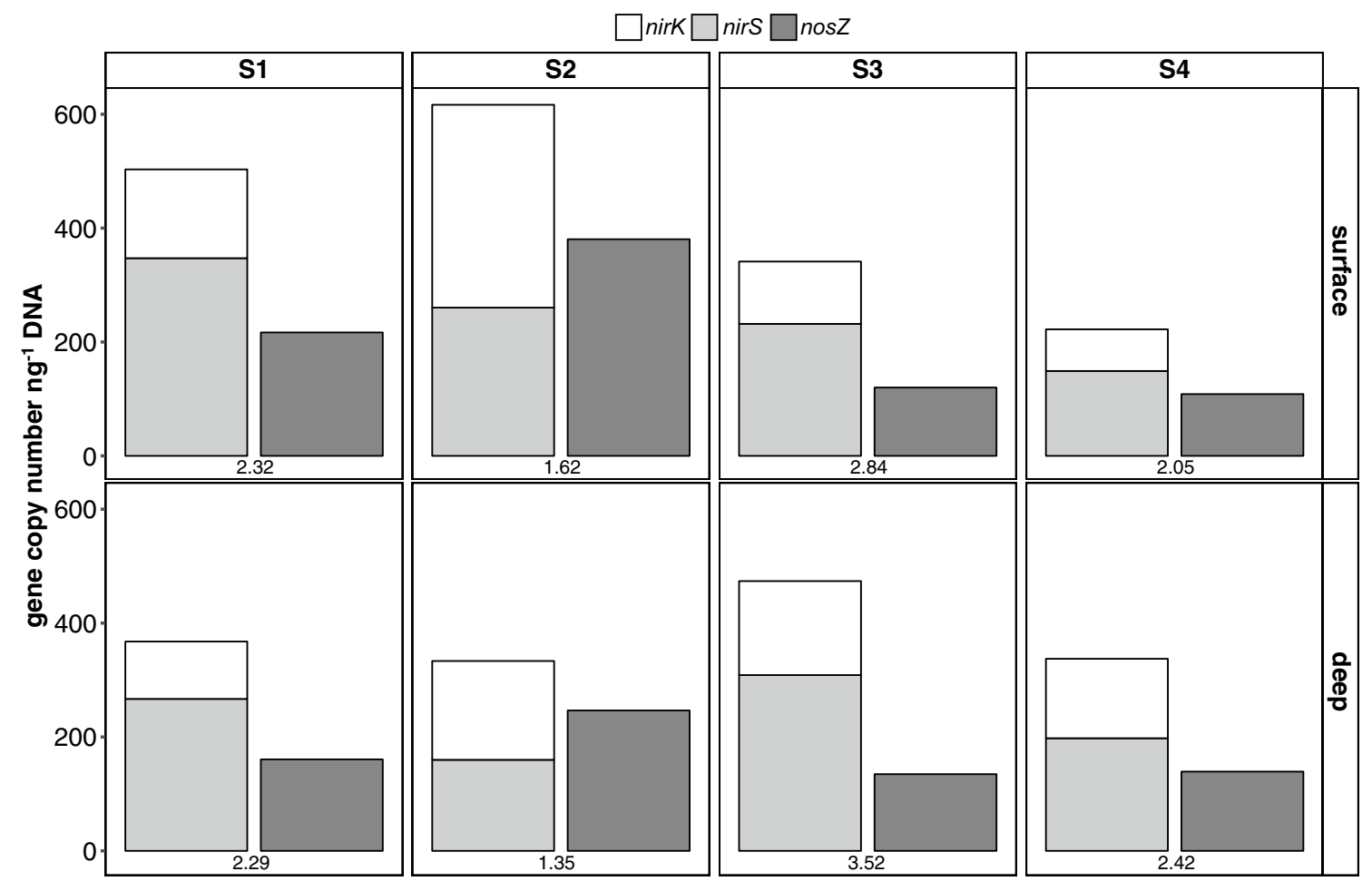

Fig. 2 The abundances of nirK, nirS and nos $Z$ genes in deep and surface sediment samples at four sampling points. The number below bars denote the ratio between nirK + nirS and nosZ 
$\rho=0.89, \mathrm{p}<0.001)$, and decreasing with higher proportion of fields and nitrite + nitrate (field $\%: \rho=-0.81, \mathrm{p}<0.001$, nitrite + nitrate: $\rho=-0.72, \mathrm{p}<0.001)$, as nirS abundance remained high while the abundance of nos $Z$ decreased at S3 and S4 (Suppl. Figure 2). The ratio was also negatively correlated with LOI\% $(\rho=-0.98, p<0.001), \% \mathrm{C}(\rho=-0.75$, $\mathrm{p}<0.001)$, and D15 $(\rho=-0.69, \mathrm{p}=0.001)$, indicating that carbon availability could limit the last step of denitrification and $\mathrm{N}_{2}$ production potential through affecting the denitrification gene abundances (Suppl. Figure 2). This finding is in agreement with the previous studies from soil environment (Attard et al. 2011; Petersen et al. 2012), where denitrification potential increased with increasing organic carbon, and was directly linked to nos $Z$ gene abundance. Furthermore, the importance of carbon in controlling the end product of denitrification is supported by connection between higher carbon availability (higher ecosystem respiration) and decreased $\mathrm{N}_{2} \mathrm{O}$ yield from denitrification in streams (Beaulieu et al. 2011).

\section{Denitrifying microbial communities}

Denitrifier communities exhibited different diversity and richness patterns. The diversity and richness of nirK community increased from S1 to S4 both in deep and surface sediment samples, while in the nirS and nos $Z$ communities, the diversity peaked at $S 2$, and species richness increased at $\mathrm{S} 2$ and $\mathrm{S} 4$ in deep sediment samples (Fig. 3). The nosZ diversity and species richness were always lower than that of the other communities due to lower sequencing depth
(Fig. 3). The correlation analysis indicated that the nirK diversity increased with the higher proportion of peatlands and with increasing ammonium concentrations (peatland\%: $\rho=0.75, p<0.001$, ammonium: $\rho=0.74, p<0.001)$, and decreased with increasing nitrate concentration $(\rho=-0.62$, $\mathrm{p}=0.007)$. The nirK species richness behaved similarly to nirK diversity, indicating that prevailing environmental conditions support nirK carrying community throughout Löytynoja, and that nirK OTUs could accumulate to S4 collecting organic material from the upper stream parts. However, nirK communities exhibited lower diversity at nitrate-rich $\mathrm{S} 2$, which could be explained with some nirK community members being DNRA microbes (Helen et al. 2016), which are commonly promoted in environments with lower nitrate concentrations and high organic $\mathrm{C}$ loading (Hardison et al. 2015), and would thus be suppressed in nitrate-rich conditions, decreasing the overall nirK community diversity. The diversities of both nirS and nos $Z$ communities were connected to land-use (field $\%$ vs. nirS: $\rho=0.97, \mathrm{p}<0.001$, nos $Z$ : $\rho=0.45, \mathrm{p}=0.020$ ) as well as sediment quality (LOI vs. nirK: $\rho=0.84, \mathrm{p}<0.001$, nosZ: $\rho=0.59, \mathrm{p}=0.002 ; \% \mathrm{C}$ vs. nirK: $\rho=0.58, \mathrm{p}=0.002$, nos $Z: \rho=0.91, \mathrm{p}<0.001 ; \% \mathrm{~N}$ vs. nirK: $\rho=0.74, \mathrm{p}<0.001$, nos $Z$ : $\rho=0.86, \mathrm{p}<0.001$; Suppl. Figure 2), and nirS diversity increased with D15 ( $\rho=0.44$, $\mathrm{p}=0.026$ ), agreeing with the previous results on long-term $\mathrm{N}$ fertilization increasing both nirS and nos $Z$ diversity (Bowen et al. 2013; Kearns et al. 2015) and denitrification rates (Peng et al. 2016) in salt marsh sediments. The species richness of nirS correlated with the sediment quality (\% $\mathrm{C}: \rho=0.74, \mathrm{p}<0.001, \% \mathrm{~N}: \rho=0.56, \mathrm{p}=0.003)$, and $n o s Z$
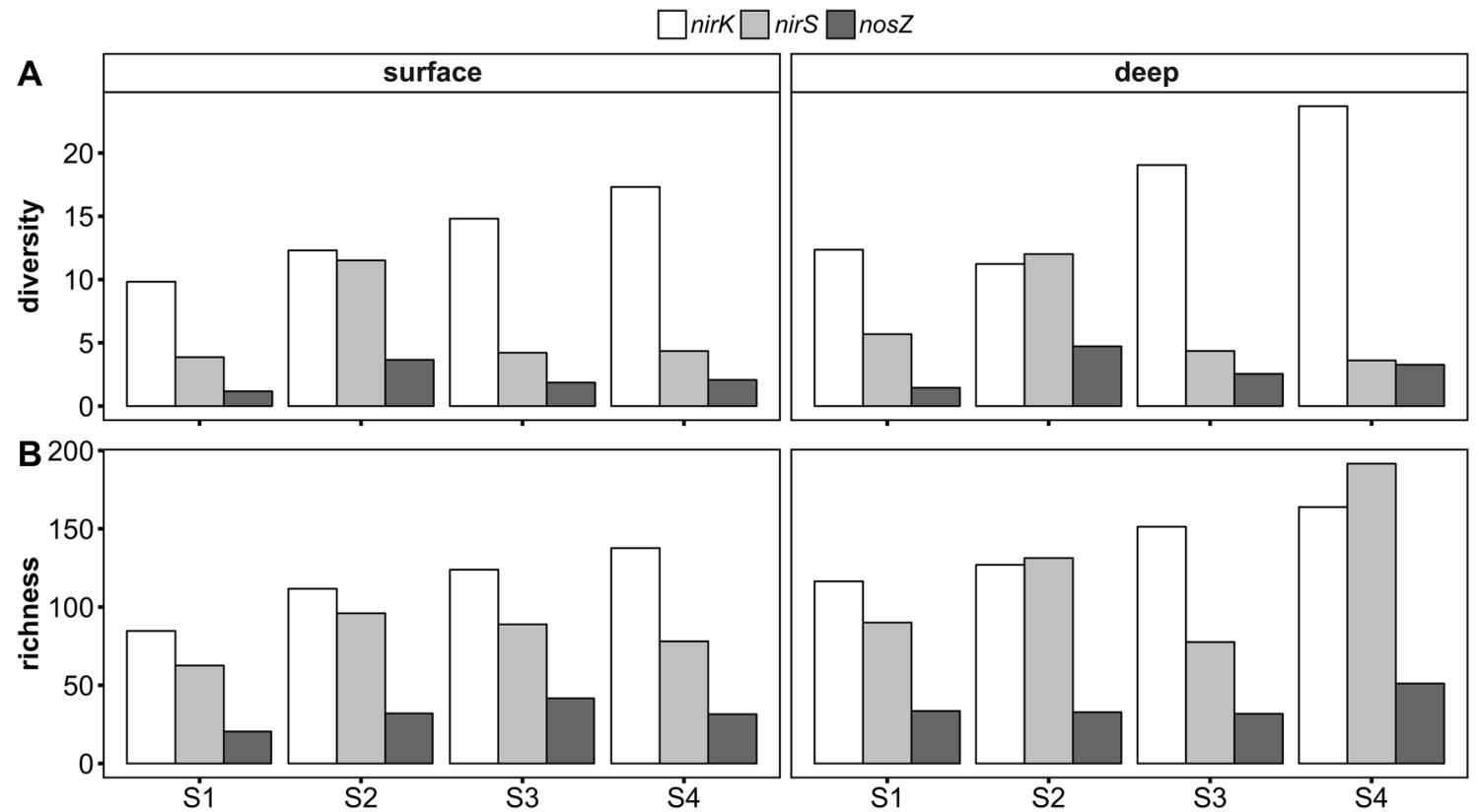

Fig. 3 a The diversity, and $\mathbf{b}$ species richness of nirK, nirS and nos Z communities in deep and surface sediment samples at four sampling points 
species richness was positively correlated with peatland proportion $(\rho=0.74, p<0.001)$ and related environmental factors (DOC: $\rho=0.86, \mathrm{p}<0.001, \mathrm{NH}_{4}^{+}: \rho=0.73, \mathrm{p}<0.001$; Suppl. Figure 2). For both nirS and nosZ, the high species richness and low diversity at $\mathrm{S} 4$ could indicate that OTUs could accumulate there from the other sampling points or come with the catchment loading, but the habitat characteristics still only support the abundance of certain OTUs. At
S2, the high nirS and nos Z diversity and species richness suggests that $\mathrm{N}$-rich loading coming from catchment with agriculture-dominated land-use type supports novel denitrifiers by providing more niche space (Bowen et al. 2013).

The nirK and nirS communities clustered with landuse, S2 being separated from the other three sampling points, especially from the peatland-dominated S3 (Fig. 4). In nirK community, OTU1 (alphaproteobacterial
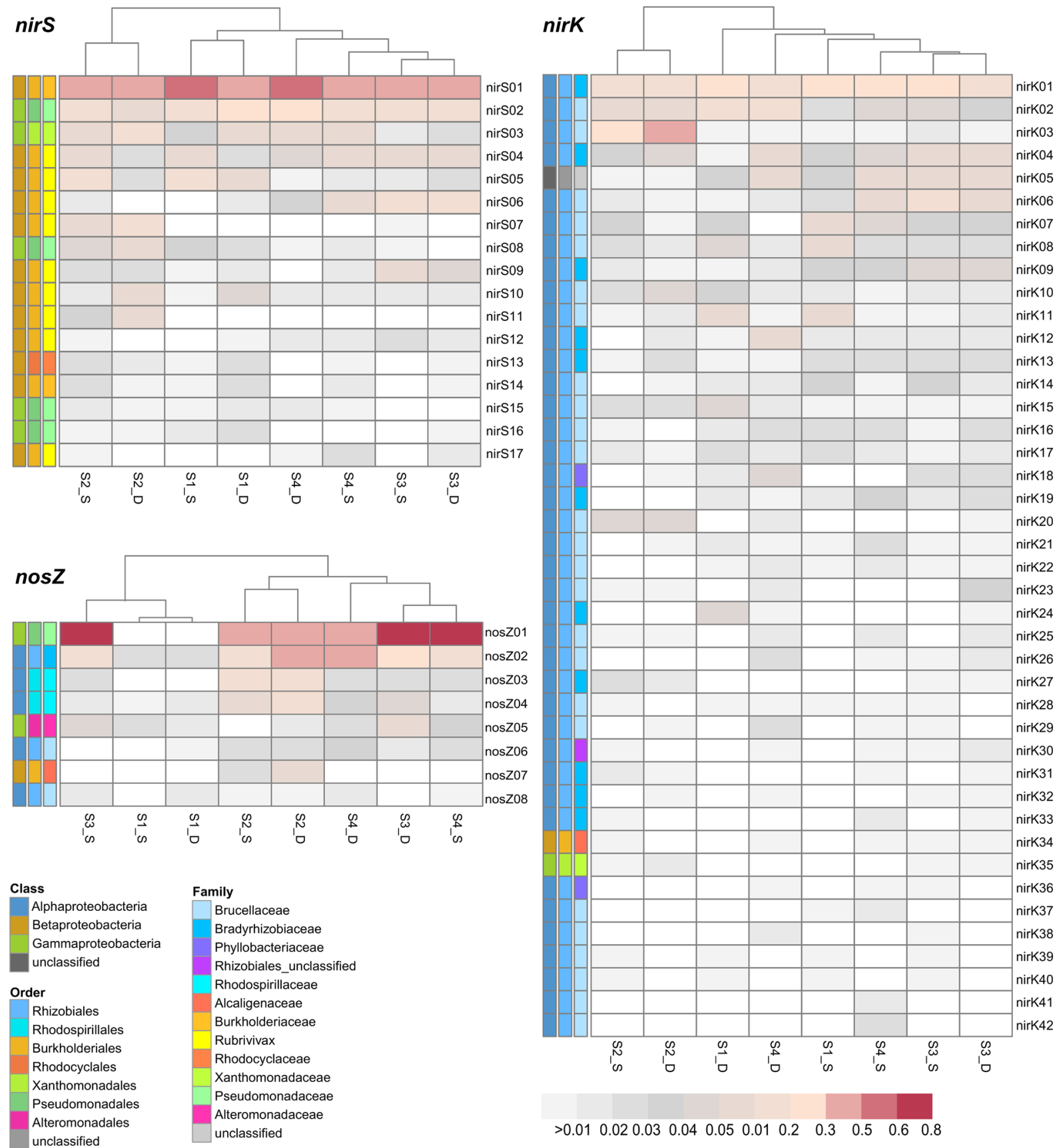

Fig. 4 Heatmaps presenting the relative abundance of the core OTUs (representing $80 \%$ of total sequences) and UPGMA clusters of sampling point microbial communities in nirS, nosZ, and nirK communities in deep and surface sediment samples at four sampling points 
Bradyrhizobiaceae; $13-30 \%$ of sequences in samples) was equally abundant at all sampling points, while OTU2 and OTU3 (alphaproteobacterial Brucellaceae) were more abundant at S2, and in the pooled S1 sample than in the five other samples. In the nirS community, the abundances of OTU1 (betaproteobacterial Burkholderiaceae) and OTU2 (gammaproteobacterial Pseudomonadaceae), comprising 41-78\% of sequences in samples, were lower at S2 than at the other sampling points. Furthermore, OTU3 (gammaproteobacterial Xanthomonadaceae; $2-14 \%$ sequences) was more abundant at both $\mathrm{S} 1$ and $\mathrm{S} 2$ than the other two sampling points. Interestingly, OTUs representing betaproteobacterial Rubrivivax (OTU4-7, 9-12, 17) did not show a uniform pattern between the sampling points. The response of nos $Z$ community was more diverse than of nitrite reducing communities, as samples from the two denitrification hotspot sampling points ( $\mathrm{S} 2$ and pooled sample from $\mathrm{S} 4$ ) were grouped together. This was mainly explained with lower abundance of OTU1 (gammaproteobacterial Pseudomonadaceae) and higher abundances of OTUs 2-4 (alphaproteobacterial Bradyrhizobiaceae and Rhodospirillaceae) at these sampling points. When inspecting the co-abundance patterns between nos and nir communities (data not shown), we observed that the relative abundance of sequences related to OTUs possessing only nos $Z$ was higher at S2 (27\% of nos Z seqs) than at other sampling points (3-12\% of nos $Z$ seqs). The abundance of nosZ OTUS having nirK increased in S2 and pooled S4 samples (25-45\% of nosZ seqs), while the relative abundance of nosZ OTUs having also $\operatorname{nir} S$ was high in all other samples (48-93\% of nos $Z$ seqs). Altogether, our results suggest that certain key taxa, possessing only nos $Z$ or both $n o s Z$ and nirK, were favoured by land-use-driven $\mathrm{N}$ amendment and higher organic matter availability, and could explain the higher denitrification potential at S2 and S4.

\section{The effect of land-use on stream denitrification}

Land-use can shape nitrate removal in the receiving streams and lakes, as has been suggested in the previous studies focusing either on microbial analysis (Bruesewitz et al. 2011) or evaluation of the denitrification potential (Arango et al. 2007; Eberhard et al. 2018; Inwood et al. 2005, 2007). Here, we combined the information on the abundance and community composition of denitrifying microbes to the isotope-based potential denitrification rate measurements for a more thorough evaluation on the effect of land-use on nitrate removal in a boreal stream. We demonstrated that the high substrate (nitrate) and carbon availability at the agriculture-dominated sampling point (S2) increased the genetic denitrification potential (denitrification gene abundance) and the abundance of certain key taxa and the overall diversity of denitrifying microbial communities. Concomitantly, we found high potential denitrification rates at that sampling point, indicating that catchment land-use can affect $\mathrm{N}$ removal potential through altering abundance but also community composition of denitrifying bacteria, agreeing with previous findings from salt marsh sediments (Angell et al. 2018). However, high potential denitrification rates were also found at the lowest sampling point with peatlanddominated catchment area, but with high accumulation of organic matter originating from the whole upper catchment area. In conclusion, our results suggest that in addition to the catchment land-use, organic matter is the key factor in controlling $\mathrm{N}$ removal in Löytynoja, and possibly in other boreal streams receiving high $\mathrm{N}$ loading. Furthermore, as both community diversity and abundance of nos $Z$ increased in sediments receiving high organic matter and $\mathrm{N}$ loading, our results imply that catchment land-use and sediment organic matter could especially regulate $\mathrm{N}_{2} \mathrm{O}$ yield from denitrification.

We acknowledge that our data are limited due to low number of data points taken only in one stream, so further studies on the land-use driven changes in nitrogen transforming microbial communities are needed for corroborating these findings. Nevertheless, our results suggest that in the future, when higher catchment loading and browning of aquatic ecosystems is expected (Kritzberg et al. 2014), the land-use type, together with water velocity affecting organic matter accumulation, could define $\mathrm{N}$ removal capacity in streams, as well as control whether they become $\mathrm{N}_{2} \mathrm{O}$ sinks or sources through altering denitrifier abundance and community composition.

Acknowledgements Open access funding provided by University of Eastern Finland (UEF) including Kuopio University Hospital. We thank Lammi Biological Station, University of Helsinki, for providing the facilities for sampling, water chemistry analysis and data analyses, Anna Taskinen for helping with the DNA extractions and Kimmo Mattila for helping with bioinformatics.

Funding This work was supported by the Academy of Finland Projects (310302 to SLA, 127922 to LA, 260797 to MT, 286642 to AJR), ENSTE graduate school grant for JS, and European Research Council (ERC) CoG project (615146 to MT).

\section{Compliance with ethical standards}

Conflict of interest The authors declare that they have no conflict of interest.

Open Access This article is distributed under the terms of the Creative Commons Attribution 4.0 International License (http://creativeco mmons.org/licenses/by/4.0/), which permits unrestricted use, distribution, and reproduction in any medium, provided you give appropriate credit to the original author(s) and the source, provide a link to the Creative Commons license, and indicate if changes were made. 


\section{References}

Aalto SL, Saarenheimo J, Ropponen J, Juntunen J, Rissanen AJ, Tiirola M (2018) Sediment diffusion method improves wastewater nitrogen removal in the receiving lake sediments. Water Res 138:312-322

Angell JH, Peng X, Ji Q, Craick I, Jayakumar A, Kearns PJ, Ward BB, Bowen JL (2018) Community composition of nitrous oxiderelated genes in salt marsh sediments exposed to nitrogen enrichment. Front Microbiol 9:170

Arango CP, Tank JL, Schaller JL, Royer TV, Bernot MJ, David MB (2007) Benthic organic carbon influences denitrification in streams with high nitrate concentration. Freshw Biol 52(7):1210-1222

Arvola L, Salonen K, Keskitalo J, Tulonen T, Järvinen M, Huotari J (2014) Plankton metabolism and sedimentation in a small boreal lake - a long-term perspective. Boreal Environ Res 19(A):83-96

Arvola L, Einola E, Järvinen M (2015) Landscape properties and precipitation as determinants for high summer nitrogen load from boreal catchments. Landsc Ecol 30:429-442

Attard E, Recous S, Chabbi A, De Berranger C, Guillaumaud N, Labreuche J, Philoppot L, Schmid B, Le Roux X (2011) Soil environmental conditions rather than denitrifier abundance and diversity drive potential denitrification after changes in land uses. Glob Change Biol 17(5):1975-1989

Beaulieu JJ, Tank JL, Hamilton SK, Wollheim WM, Hall RO, Mulholland PJ, Peterson BJ, Ashkenas LR, Cooper LW, Dahm CN, Dodds WK, Grimm NB, Johnson SL, McDowell WH, Poole GC, Valett HM, Arango CP, Bernot MJ, Burgin AJ, Crenshaw CL, Helton AM, Johnson LT, O'Brien JM, Potter JD, Sheibley RW, Sobota DJ, Thomas SM (2011) Nitrous oxide emission from denitrification in stream and river networks. Proc Natl Acad Sci USA 108(1):214-219

Bowen JL, Byrnes JE, Weisman D, Colaneri C (2013) Functional gene pyrosequencing and network analysis: an approach to examine the response of denitrifying bacteria to increased nitrogen supply in salt marsh sediments. Front Microbiol 4:342

Bruesewitz DA, Hamilton DP, Schipper LA (2011) Denitrification potential in lake sediment increases across a gradient of catchment agriculture. Ecosystems 14(3):341-352

Chao A (1984) Nonparametric estimation of the number of classes in a population. Scand J Stat 11:265-270

Eberhard EK, Marcarelli AM, Baxter CV (2018) Co-occurrence of in-stream nitrogen fixation and denitrification across a nitrogen gradient in a western US watershed. Biogeochemistry 139(2):179-195

Enwall K, Throbäck IN, Stenberg M, Söderström M, Hallin S (2010) Soil resources influence spatial patterns of denitrifying communities at scales compatible with land management. Appl Environ Microbiol 76(7):2243-2250

Galloway JN, Schlesinger WH, Clark CM, Grimm NB, Jackson RB, Law BE, Thornton PE, Townsend AR, Martin R (2014) Biogeochemical cycles, chapter 15. In: Melillo JM, Richmond TC, Yohe GW (eds) Climate change impacts in the United States: the third national climate assessment, U.S. Global Change Research Program, pp 350-368. https://doi.org/10.7930/j0x63jt0

Griffiths RI, Whiteley AS, O'Donnell AG, Bailey MJ (2000) Rapid method for coextraction of DNA and RNA from natural environments for analysis of ribosomal DNA-and rRNA-based microbial community composition. Appl Environ Microbiol 66(12):5488-5491

Hakala I, Huitu E, Mäkelä S, Arvola L (2002) Impacts of land-use on concentrations of nutrients in runoffs: preliminary results in small catchment areas. Large Rivers 13:285-303
Hallin S, Lindgren PE (1999) PCR detection of genes encoding nitrite reductase in denitrifying bacteria. Appl Environ Microbiol 65(4): 1652-1657

Hardison AK, Algar CK, Giblin AE, Rich JJ (2015) Influence of organic carbon and nitrate loading on partitioning between dissimilatory nitrate reduction to ammonium (DNRA) and $\mathrm{N}_{2}$ production. Geochim Cosmochim Acta 164:146-160

Helen D, Kim H, Tytgat B, Anne J (2016) Highly diverse nirK genes comprise two major clades that harbour ammonium-producing denitrifiers. BMC Genomics 17(1):155

Henry S, Baudoin E, López-Gutiérrez JC, Martin-Laurent F, Brauman A, Philippot L (2004) Quantification of denitrifying bacteria in soils by nirK gene targeted real-time PCR. J Microbiol Methods 59(3):327-335

Henry S, Bru D, Stres B, Hallet S, Philippot L (2006) Quantitative detection of the nos $Z$ gene, encoding nitrous oxide reductase, and comparison of the abundances of $16 \mathrm{~S}$ rRNA, narG, nirK, and nosZ genes in soils. Appl Environ Microbiol 72(8):5181-5189

Huotari J, Nykänen H, Forsius M, Arvola L (2013) Effect of catchment characteristics on aquatic carbon export from a boreal catchment and its importance in regional carbon cycling. Glob Change Biol 19(12):3607-3620

Inwood SE, Tank JL, Bernot MJ (2005) Patterns of denitrification associated with land use in 9 midwestern headwater streams. J N Am Benthol Soc 24(2):227-245

Inwood SE, Tank JL, Bernot MJ (2007) Factors controlling sediment denitrification in midwestern streams of varying land use. Microb Ecol 53(2):247-258

Jarvie HP, Sharpley AN, Kresse T, Hays PD, Williams RJ, King SM, Berry L (2018) Coupling high-frequency stream metabolism and nutrient monitoring to explore biogeochemical controls on downstream nitrate delivery. Environ Sci Technol 52:13708-13717

Jones CM, Graf DR, Bru D, Philippot L, Hallin S (2013) The unaccounted yet abundant nitrous oxide-reducing microbial community: a potential nitrous oxide sink. ISME J 7(2):417-426

Kandeler E, Deiglmayr K, Tscherko D, Bru D, Philippot L (2006) Abundance of narG, nirS, nirK, and nosZ genes of denitrifying bacteria during primary successions of a glacier foreland. Appl Environ Microbiol 72(9):5957-5962

Kearns PJ, Angell JH, Feinman SG, Bowen JL (2015) Long-term nutrient addition differentially alters community composition and diversity of genes that control nitrous oxide flux from salt marsh sediments. Estuar Coast Shelf Sci 154:39-47

Kloos K, Mergel A, Rösch C, Bothe H (2001) Denitrification within the genus Azospirillum and other associative bacteria. Funct Plant Biol 28(9):991-998

Kritzberg ES, Granéli W, Björk J, Brönmark C, Hallgren P, Nicolle A, Persson A, Hansson LA et al (2014) Warming and browning of lakes: consequences for pelagic carbon metabolism and sediment delivery. Freshw Biol 59(2):325-336

Laine MPP, Strömmer R, Arvola L (2013) Nitrogen release in pristine and drained peat profiles in response to water table fluctuations: a mesocosm experiment. Appl Environ Soil Sci 2013:694368

Laine MPP, Strömmer R, Arvola L (2014) DOC and CO2-C releases from pristine and drained peat soils in response to water table fluctuations: a mesocosm experiment. Appl Env Soil Sci 2014:912816

Mulholland PJ, Helton AM, Poole GC, Hall RO, Hamilton SK, Peterson BJ, Tank JL, Ashkenas LR, Cooper LW, Dahm CN, Dodds WK, Findlay SEG, Gregory SV, Grimm NB, Johnson SL, McDowell WH, Meyer JL, Valett HM, Webster JR, Arango CP, Beualieu JJ, Bernot MJ, Burgin AJ, Crenshaw CL, Johnson LT, Niederlehner BR, O'Brien JM, Potter JD, Sheibley RW, Sobota DJ, Thomas SM (2008) Stream denitrification across biomes and its response to anthropogenic nitrate loading. Nature 452(7184):202-205 
National Land Survey of Finland (2010) Topographic database. Archived from the original in March 2012

National Land Survey of Finland (2016) Elevation model $2 \mathrm{~m}$. Archived from the original in March 2016

Nielsen LP (1992) Denitrification in sediment determined from nitrogen isotope pairing. FEMS Microbiol Lett 86(4):357-362

Peng X, Ji Q, Angell JH, Yang HJ, Bowen JL, Ward BB (2016) Longterm fertilization alters the relative importance of nitrate reduction pathways in salt marsh sediments. J Geophys Res Biogeosci 121(8):2082-2095

Petersen DG, Blazewicz SJ, Firestone M, Herman DJ, Turetsky M, Waldrop M (2012) Abundance of microbial genes associated with nitrogen cycling as indices of biogeochemical process rates across a vegetation gradient in Alaska. Environ Microbiol 14(4):993-1008

Peterson BJ, Wollheim WM, Mulholland PJ, Webster JR, Meyer JL, Tank JL, Martí E, Bowden WB, Valett HM, Hershey AE, McDowell WH, Dodds WK, Hamilton SK, Gregory S, Morrall DD (2001) Control of nitrogen export from watersheds by headwater streams. Science 292(5514):86-90

Rissanen AJ, Kurhela E, Aho T, Oittinen T, Tiirola M (2010) Storage of environmental samples for guaranteeing nucleic acid yields for molecular microbiological studies. Appl Microbiol Biotechnol 88(4):977-984

Rissanen A, Tiirola M, Ojala A (2011) Spatial and temporal variation in denitrification and in the denitrifier community in a boreal lake. Aquat Microb Ecol 64:27-40

Rissanen A, Tiirola M, Hietanen S, Ojala A (2013) Interlake variation and environmental controls of denitrification across different geographical scales. Aquat Microb Ecol 69(1):1-16

Saarenheimo J, Rissanen AJ, Arvola L, Nykänen H, Lehmann M, Tiirola $\mathrm{M}$ (2015a) Genetic and environmental controls on nitrous oxide accumulation in lakes. PLoS One 10(3):e0121201
Saarenheimo J, Tiirola MA, Rissanen AJ (2015b) Functional gene pyrosequencing reveals core proteobacterial denitrifiers in boreal lakes. Front Microbiol 6:674

Sanford RA, Wagner DD, Wu Q, Chee-Sanford JC, Thomas SH, CruzGarcía C, Rodríguez G, Massol-Deyá A, Krishnani KK, Ritalahti KM, Nissen S, Konstantinidis KT, Löffler FE (2012) Unexpected nondenitrifier nitrous oxide reductase gene diversity and abundance in soils. Proc Natl Acad Sci USA 109(48):19709-19714

Schloss PD, Westcott SL, Ryabin T, Hall JR, Hartmann M, Hollister EB, Lesniewski RA, Oakley BB, Parks DH, Robinson CJ, Sahl JW, Stres B, Thallinger GG, Van Horn DJ, Weber CF (2009) Introducing mothur: open-source, platform-independent, communitysupported software for describing and comparing microbial communities. Appl Environ Microbiol 75(23):7537-7541

Seitzinger S, Harrison JA, Böhlke JK, Bouwman AF, Lowrance R, Peterson B, Tobias C, Drecht GV (2006) Denitrification across landscapes and waterscapes: a synthesis. Ecol Appl 16(6):2064-2090

Throbäck IN, Enwall K, Jarvis Å, Hallin S (2004) Reassessing PCR primers targeting nirS, nirK and nosZ genes for community surveys of denitrifying bacteria with DGGE. FEMS Microbiol Lett 49(3):401-417

Tomasek AA, Barman TD, Wang P, Kozarek JL, Staley C, Sadowsky MJ, Hondzo M (2018) The effects of turbulence and carbon amendments on nitrate uptake and microbial gene abundances in stream sediment. J Geophys Res Biogeosci 123(4):1289-1301

Publisher's Note Springer Nature remains neutral with regard to jurisdictional claims in published maps and institutional affiliations. 